JESUS CG; SILVA JÚNIOR FJ; CAMARA TR; SILVA EFF; WILLADINO L. 2015. Production of rocket under salt stress in hydroponic systems. Horticultura Brasileira 33: 493-497. DOI - http://dx.doi.org/10.1590/S0102-053620150000400014

\title{
Production of rocket under salt stress in hydroponic systems
}

\author{
Cléoma G Jesus; Fernando J Silva Júnior; Terezinha R Camara; Ênio FF Silva; Lilia Willadino \\ UFRPE, Recife-PE, Brasil; cleo_mila21@hotmail.com; nando_fj18@hotmail.com; teca.camara@gmail.com; enio.silva@pq.cnpq.br; \\ willadino.lilia@gmail.com; lilia@pq.cnpq.br
}

\begin{abstract}
Salinity is one of the most limiting abiotic stresses in crop production worldwide. In this study, two rocket cultivars (Cultivada and Folha Larga) were grown in hydroponic system (nutrient film technique) under six treatments. The control comprised a nutrient solution without salt addition, and the other treatments contained different $\mathrm{NaCl}$ concentrations in the nutrient solution, resulting in the following electrical conductivities: $1.8,3.8,5.8,7.8,9.7$ and $11.8 \mathrm{dS} / \mathrm{m}$. The experimental design was completely randomized (6x2) with six levels of salt and two rockets cultivars, with four replicates per treatment. Increasing salinity reduced the fresh and dry mass of the leaves, roots, and the protein content, but the proline content was increased. The enzymatic activity of catalase (CAT), ascorbate peroxidase (APX) and polyphenoloxidase (PPO) increased with salinity. The activity of CAT and PPO of cv. Folha Larga was higher than of cv. Cultivada and coincided with a greater production of biomass in leaves and roots, showing the effectiveness of the antioxidative defense system in maintaining the growth of genotypes under increasing salinity of the solution.
\end{abstract}

Keywords: Eruca sativa, antioxidant enzymes, NFT.

\section{RESUMO}

Produção de rúcula sob estresse salino em sistema hidropônico

A salinidade é um dos estresses abióticos que mais limita a produtividade das culturas em todo o mundo. No presente trabalho, duas cultivares de rúcula (Cultivada e Folha Larga), cultivadas em sistema hidropônico (fluxo laminar de nutrientes) foram submetidas a seis tratamentos. O controle foi constituído pela solução nutritiva sem a adição de sal e os demais mediante a adição de $\mathrm{NaCl}$ à solução nutritiva resultando nas seguintes condutividades elétrica: 1,$8 ; 3,8$; 5,$8 ; 7,8 ; 9,7$ e $11,8 \mathrm{dS} / \mathrm{m}$. O delineamento experimental utilizado foi inteiramente casualizado (6x2) com seis níveis de sal e duas cultivares de rúcula, com quatro repetições por tratamento. O incremento da salinidade reduziu a massa fresca e seca das folhas e raizes, e o teor de proteína, porém o teor de prolina foi aumentado. As enzimas catalase (CAT), peroxidase do ascorbato (APX) e polifenoloxidase (PPO) tiveram suas atividades aumentadas com o incremento da salinidade. A atividade da CAT e PPO na cv. Folha Larga foi superior à da Cultivada e coincidiu com uma maior produção de biomassa seca em folhas e raízes, mostrando a eficácia do sistema de defesa antioxidante em manter o crescimento do genótipo frente ao aumento da salinidade na solução de cultivo.

Palavras-chave: Eruca sativa, enzimas antioxidativas, NFT.

(Recebido para publicação em 10 de fevereiro de 2014; aceito em 6 de abril de 2015)

(Received on February 10, 2014; accepted on April 6, 2015)

$I^{\mathrm{n}} \mathrm{n}$ northeastern Brazil, salt-affected soils occupy an area of approximately 9.1 million hectars (Fageria et al., 2010), and the water in wells drilled to capture groundwater is generally low flow and present high salt levels. One of the most viable alternatives for the use of saline soils and brackish waters is the use of tolerant plant varieties (Flowers, 2004). The use of hydroponic techniques associated with the tolerant varieties greatly increases the efficiency of water use. Salinity is an abiotic factor that causes stress in plants, limiting their growth and productivity (Munns \& Tester, 2008). Environmental stress causes the accumulation of reactive oxygen species (ROS), resulting in oxidative stress (Miller et al., 2010). Plants have mechanisms to protect cellular and subcellular structures against the effects of ROS through the activation of antioxidant enzyme systems (Agarwal \& Pandei, 2004), including ascorbate peroxidase (APX), catalase (CAT) and polyphenoloxidase (PPO). The enzymes APX and CAT catalyze the decomposition of $\mathrm{H}_{2} \mathrm{O}_{2}$ and play a key role in maintaining redox balance (Miller et al., 2010). The increased activity of one or more antioxidant enzymes due to an increase in salinity has been recorded in several plant species (Bor et al., 2003; Agarwal \& Shaheen, 2007; Koca et al., 2007; Maia et al., 2010). The increased activity of antioxidant enzymes prevents and reduces damage to nucleic acids, proteins and membranes, while maintaining redox homeostasis (Foyer \& Noctor, 2009). The rocket (Eruca sativa) is an edible plant with peppery flavored leaves, rich in vitamin $\mathrm{C}$ and $\mathrm{E}$, potassium, sulfur, iron and calcium, and it is considered moderately sensitive to salinity (Silva et al., 2011). The present study aimed at evaluating the response to salinity of two rocket cultivars, 
cultivated in a hydroponic system through the assessment of growth and the characterization of antioxidant system enzymes.

\section{MATERIAL AND METHODS}

The experiments were conducted in a greenhouse $\left(8^{\circ} 4^{\prime} 3^{\prime}\right.$ S, $\left.34^{\circ} 55^{\prime} 00 \mathrm{~W}\right)$, where the average air temperature was $25.5^{\circ} \mathrm{C}$, ranging from 26.4 (maximum) to 24.5 (minimum); the relative humidity was $65 \%$ and the solar radiation was 6.6 $\mathrm{Qg}\left(\mathrm{MJ} / \mathrm{m}^{2} / \mathrm{d}\right)$ under a photoperiod of 12 hours.

Rocket seeds, cultivars Folha Larga (FL) and Cultivada (Cult), were grown in phenolic foam boards $(2 \times 2 \times 2 \mathrm{~cm})$ and kept in the dark for 36 hours. After germination, the seedlings were transferred to the greenhouse and placed in a NFT system. The hydroponic structure consisted of 24 polypropylene hydroponic channels $(75 \mathrm{~mm}$ diameter, $3.0 \mathrm{~m}$ length) with holes $(2.5 \mathrm{~cm}$ radius) spaced at $0.20 \mathrm{~m}$ intervals. Each channel was maintained by an independent NFT hydroponic system consisting of a plastic reservoir $(60 \mathrm{~L})$ and an electric circulation pump. Each channel contained eight holes (four for each cultivar), with 10 plants per hole. The hydroponic irrigation system was operated by a timer, providing Furlani nutrient solution (Furlani, 1998) at regular intervals of 15 minutes at a flow rate of $1.6 \mathrm{~L} / \mathrm{min}$. The experimental design was completely randomized (6x2) with six salt levels, two rocket cultivars and four replicates per treatment. On the control treatment, the Furlani solution was used without salt addition, and on the other treatments, $\mathrm{NaCl}$ was added to the nutrient solution at different concentrations, resulting in the following electrical conductivities: $1.8,3.8,5.8,7.8,9.7$ and $11.8 \mathrm{dS} / \mathrm{m}$. The volume of the nutrient solution in the reservoir was maintained at 50 $\mathrm{L}$, and the treatments were monitored with daily measurements of electrical conductivity.

At 40 days after sowing eight fully expanded leaves of each cultivar were collected. The leaves were removed from the middle portion of the plants contained in each of the eight holes of hydroponic channels. The collected leaves were wrapped in aluminum foil, immediately immersed in liquid nitrogen, and stored in a freezer at $-80^{\circ} \mathrm{C}$ until the determination of enzymatic activity, proline and total soluble protein. The fresh weight of the leaves (FW) was obtained using a digital balance. The dry weight of the leaves (DW) and roots (DWR) was measured after drying at $70^{\circ} \mathrm{C}$ until constant weight.

The total soluble protein was determined according to the method described by Bradford (1976). The proline content was determined following the method proposed by Bates et al. (1973). The enzymatic activity of

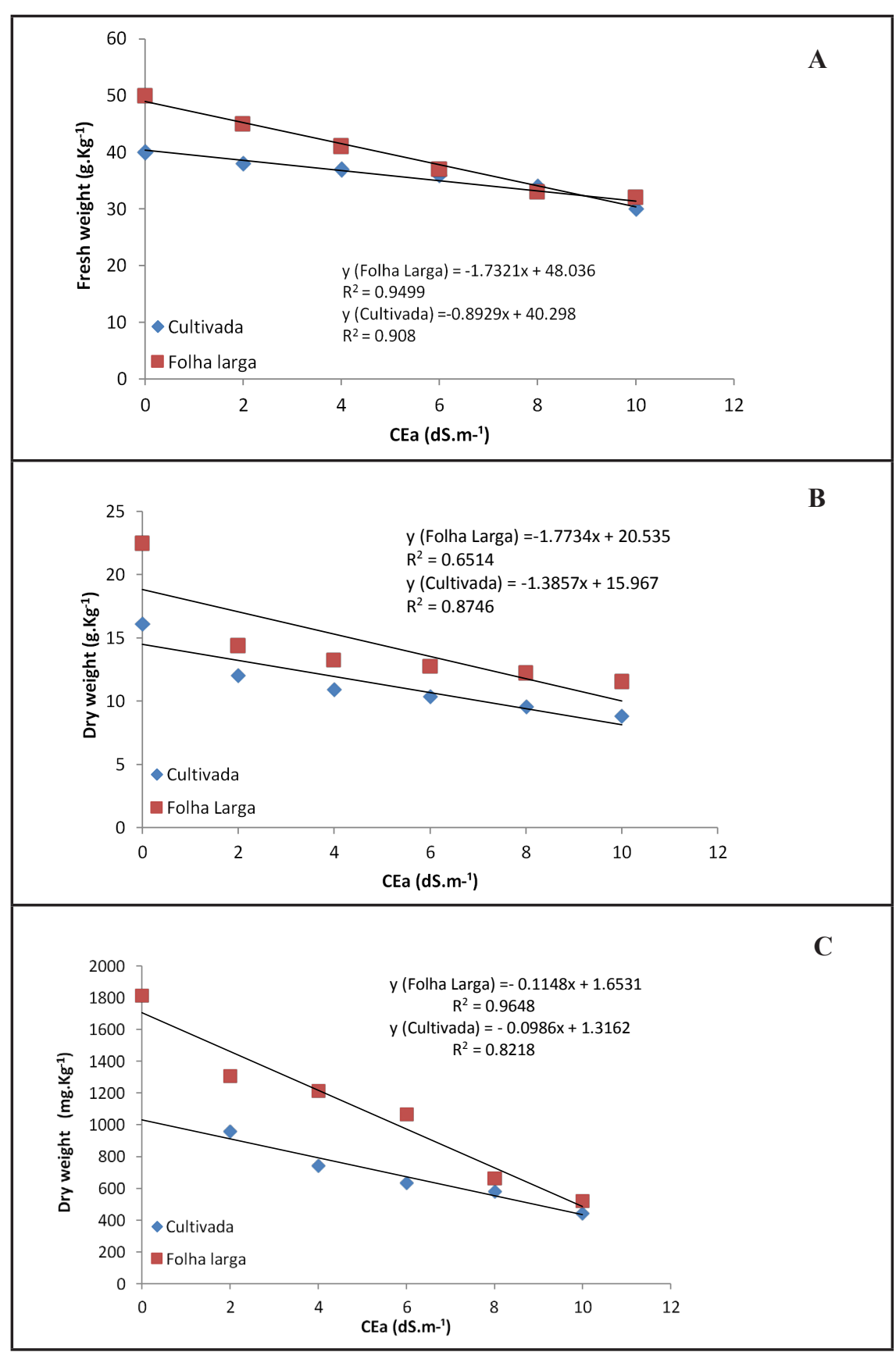

Figure 1. Fresh weight of leaves (A), dry weight of leaves (B) and roots (C) of rocket cultivars Folha Larga and Cultivada depending on increasing salinity levels \{massa fresca de folhas (A), massa seca de folhas (B), e raízes (C) de duas cultivares de rúcula Folha Larga e Cultivada em função do aumento dos níveis da salinidade\}. Recife, UFRPE, 2013. 
catalase (CAT), ascorbate peroxidase (APX) and polyphenoloxidase (PPO) was determined as described by Azevedo et al. (1998), Moldes et al. (2008) and Cano (1997), respectively. The data were subjected to analysis of variance using the SAS statistical program. The variables with significant effects ( $F$ test) were submitted to regression analysis.

\section{RESULTS AND DISCUSSION}

The increase in $\mathrm{NaCl}$ concentration resulted in a progressive reduction of fresh and dry weights of the leaves (Figure

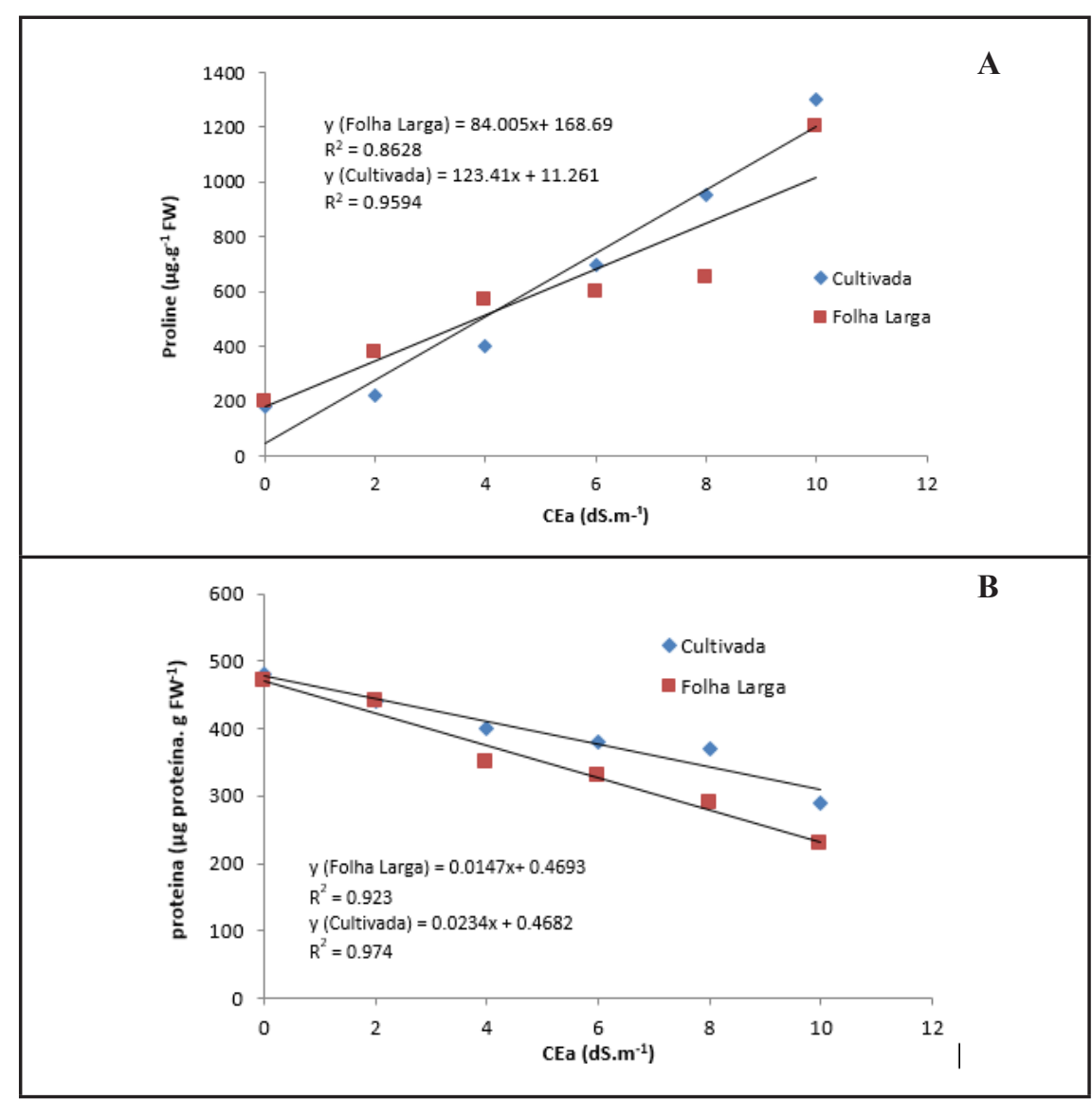

Figure 2. Proline and total soluble protein content in the leaves of rocket cultivars Folha Larga and Cultivada depending on increasing salinity levels (prolina e proteínas solúveis totais em folhas de duas cultivares de rúcula Folha Larga e Cultivada em função do aumento dos níveis da salinidade). Recife, UFRPE, 2013.
1). The reduction reached levels of 35 to $49 \%$ and 25 to $45 \%$ in Folha Larga, and Cultivada cultivars, respectively. Similarly, but more significantly, the dry root weight was reduced by 70 and $72 \%$ for the Folha Larga and Cultivada cultivar, respectively, reflecting a greater sensitivity of the roots to salt stress. All values were fitted to a negative linear model. Greater reductions (approximately 68\%) were recorded for rocket subjected to $5,2 \mathrm{dS} / \mathrm{m}$ in a NFT system (Silva et al., 2011) under the semi-arid conditions, showing the influence of environmental conditions, even in greenhouse with a hydroponic system. The reduction of fresh and dry biomass is related to the osmotic effect of salinity, the toxic effect of $\mathrm{Na}^{+}$and $\mathrm{Cl}^{-}$and the ionic imbalance caused by an excess of these ions (Munns \& Tester, 2008). The dry weight of leaves and roots was greater in the Folha Larga than Cultivada cv. (Table 1).

Proline accumulation with increasing salinity fitted a linear model (Figure 2). In vegetables, proline is frequently accumulated in response to salt stress, as demonstrated in other brassica species (Ashraf \& McNeilly, 2004) and foliar application of proline improves the performance of rocket plants and enhances the accumulation of functional metabolites under saline stress (Barbieri et al., 2011). Although accumulated proline acts as an osmoregulator and plays an important role in salinity tolerance by ensuring the reduction of cellular water potential, its significance is still controversial. Some studies have shown that the main role of proline is to protect proteins, DNA, membranes

Table 1. Mean values of fresh and dry mass of leaves, dry mass of roots, catalase, ascorbate peroxidase and polyphenoloxidase of rocket cultivars (Folha Larga and Cultivada) under hydroponic culture depending on salinity levels \{valores médios de massa fresca e seca de folhas, massa seca da raiz, catalase, ascorbato peroxidase, polifenoloxidase de cultivares de rúcula (Folha Larga e Cultivada) em cultivo hidropônico, em função dos níveis de salinidade\}. Recife, UFRPE, 2013.

\begin{tabular}{lccc}
\hline \multirow{2}{*}{ Cultivars } & Fresh mass of leaves & Dry mass of leaves & Dry mass of roots \\
\cline { 2 - 4 } & & $\mathbf{( g / k g )}$ & $1.07 \mathrm{a}$ \\
\hline Folha Larga & $39.73 \mathrm{a}$ & $14.33 \mathrm{a}$ & $0.83 \mathrm{~b}$ \\
Cultivada & $36.28 \mathrm{a}$ & $11.12 \mathrm{~b}$ & Polyphenoloxidase \\
\hline & Catalase & Ascorbate peroxidase & $11925 \mathrm{a}$ \\
\cline { 2 - 4 } & & $\mathbf{( U / m i n} / \mathbf{m g}$ proteína/g FW) \\
Folha Larga & $4517 \mathrm{a}$ & $27710 \mathrm{a}$ & $7708 \mathrm{~b}$ \\
\hline
\end{tabular}




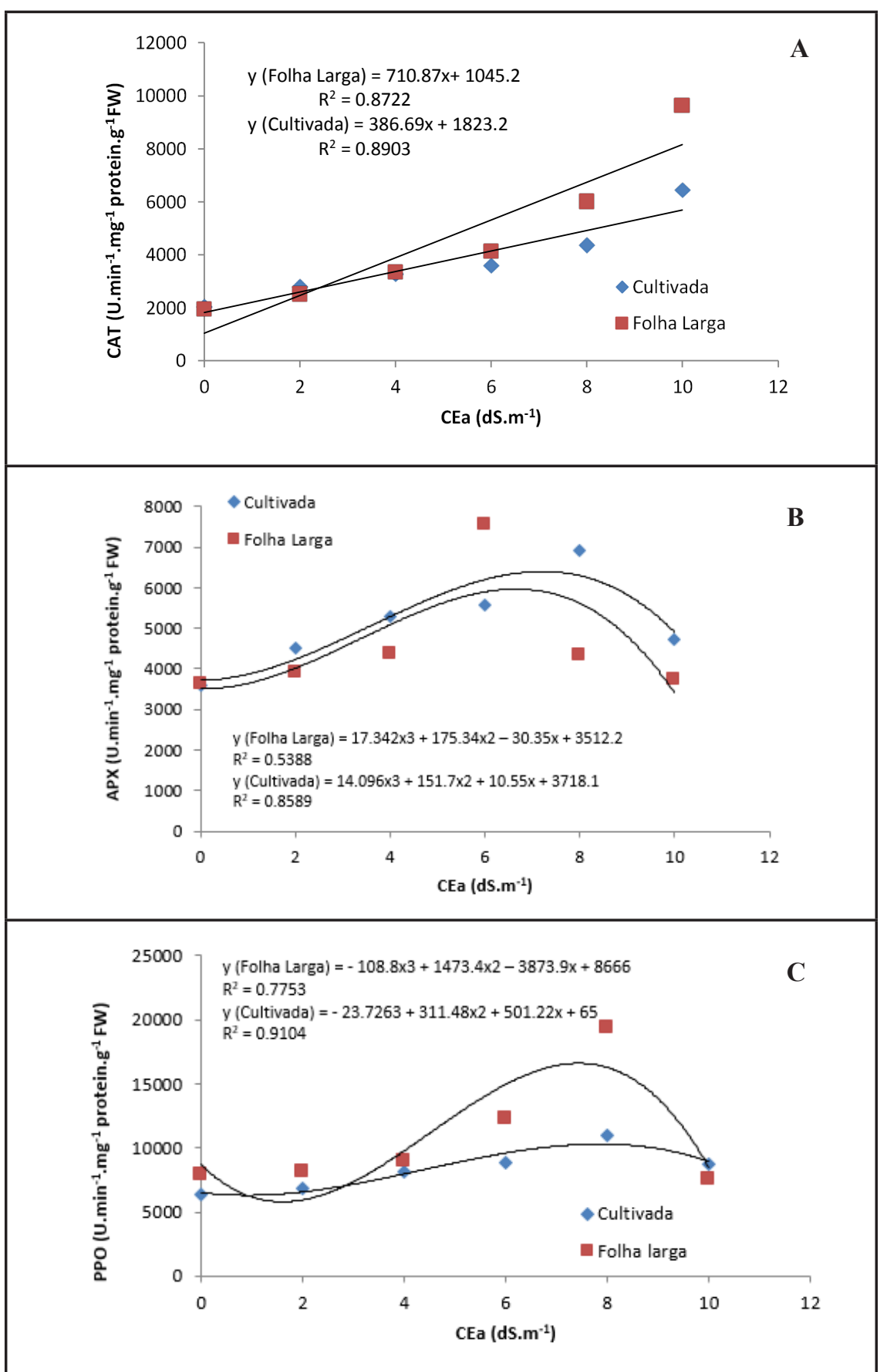

Figure 3. Enzymatic activity of catalase, ascorbate peroxidase and polyphenoloxidase in leaves of two rocket cultivars (Folha Larga and Cultivada) depending on increasing salinity levels (atividade enzimática da catalase, peroxidase e polifenoloxidase em folhas de duas cultivares de rúcula Folha Larga e Cultivada em função do aumento dos níveis da salinidade). Recife, UFRPE, 2013.

and subcellular structures (Kavi Kishor et al., 2005) against reactive oxygen species. The accumulation of proline might result from increased synthesis and/or an inhibition of catabolism, which are common mechanisms in plants under stress.

In both rocket cultivars occurred a reduction of protein (Figure 2) as a result of increased saline concentrations, reflecting a reduction in protein synthesis or accelerated degradation due to the stress imposed. There were no significant differences among proline and protein content of Folha Larga and Cultivada cultivars.
The activity of catalase (CAT), ascorbate peroxidase (APX) and polyphenoloxidase (PPO) increased significantly with the increase of salinity in the nutrient solution. The positive relationship between antioxidative activity and tolerance to $\mathrm{NaCl}$ has been demonstrated in several plant species (Sudhakar et al., 2001; Sairan et al., 2002; Meloni et al., 2003; Madhania et al., 2006). In both cultivars occurred a linear increase in CAT activity due to the presence of $\mathrm{NaCl}$ in the culture medium (Figure 3). The increased activity of enzymes that catalyze the breakdown of $\mathrm{H}_{2} \mathrm{O}_{2}$ plays an important role in the adaptation of plants under saline conditions in the regulation of $\mathrm{H}_{2} \mathrm{O}_{2}$ levels preventing its accumulation to toxic levels (Miller et al., 2010). CAT and APX belong to two different classes of enzymes based on their affinity to $\mathrm{H}_{2} \mathrm{O}_{2}$. While CAT is presumably responsible for the removal of excess ROS, APX could be responsible for fine-tuning ROS levels in response to stress (Mittler, 2002).

The cv. Folha Larga showed higher CAT activity than the Cultivada suggesting a greater efficiency in reducing oxidative stress damage under high salt concentrations (Table 1). Genotypes that are more tolerant to salt stress have increased CAT activity in comparison to those that are sensitive to salinity (Sudhakar et al., 2001; Sairan et al., 2002; Willadino et al., 2011).

Increased activity of APX and PPO was observed at levels of $7.9 \mathrm{dS} / \mathrm{m}$ salt concentrations, for both cultivars. In addition, a progressive decrease in the activity of these enzymes was observed, coincident with increased salinity levels, indicating a possible inactivation of APX and PPO in response to severe stress (Figure 3). According to Munns (2002), $\mathrm{NaCl}$ levels above $100 \mathrm{mM}$ cause the inhibition of a wide range of enzymes.

The ascorbate peroxidases are considered important for the removal of $\mathrm{H}_{2} \mathrm{O}_{2}$ in both the cytosol and the chloroplasts (Foyer \& Noctor, 2009). Generally, increased APX activity indicates genotypes with increased tolerance to $\mathrm{NaCl}$ in several species (Koca et al., 2007; Maia et al., 2010; 
Willadino et al., 2011).

The PPO activity was significantly higher in cv. Folha Larga compared to Cultivada (Table 1). The increase in PPO with $\mathrm{NaCl}$ treatments has been observed in Phaseolus vulgaris (Demir \& Kocaçaliskan, 2001), Cassia angustifolia (Agarwal \& Pandey, 2004) and Momordica charantia (Agarwal \& Shaheen, 2007). PPO catalyzes the oxidation of phenols (mono and diphenols) (Gomes et al., 2001) and is considered useful in the defense of oxidative stress induced by salinity (Agarwal \& Pandey, 2004).

The increase of enzymatic activity of CAT and PPO significantly greater in Folha Larga demonstrated the ability of this variety to activate the antioxidant enzyme system in the defense against excess of reactive oxygen species more efficiently than cv. Cultivada. The higher biomass of leaves and roots of cv. Folha Larga corroborates the beneficial role of antioxidant system in maintaining growth under imposed salt stress conditions.

\section{REFERENCES}

AGARWAL S; PANDEY V. 2004. Antioxidant enzyme responses to $\mathrm{NaCl}$ stress in Cassia angustifolia. Biologia Plantarum 48: 555-560.

AGARWAL S; SHAHEEN R. 2007. Stimulation of antioxidant system and lipid peroxidation by abiotic stresses in leaves of Momordica charantia. Brazilian Journal of Plant Physiology 19: 149-161.

ASHRAF M; McNEILLY T. 2004. Salinity tolerance in brassica oilseeds. Critical Reviews in Plant Sciences 23: 157-174.

AZEVEDO RA; ALAS RM; SMITH RJ; LEA PJ. 1998. Response of antioxidant enzymes to transfer from elevated carbon dioxide to air and ozone fumigation, in the leaves and roots of wild-type and a catalase-deficient mutant of barley. Physiologia Plantarum 104: 280-292.

BARBIERI G; BOTTINO A; VALLONE S; MAGGIO A. 2011. Proline and light as quality enhancers of rocket (Eruca sativa) grown under saline conditions. Scientia Horticulturae
128: 393-400.

BATES L; WALDREN PP; TEARE JD. 1973. Rapid determination of the free proline of water stress studies. Plant Soil 39: 205-207.

BOR M; OZDEMIR F; TURKAN I. 2003. The effect of salt stress on lipid peroxidation and antioxidants in leaves of sugar beet Beta vulgaris and wild beet Beta maritima. Plant Science 164: 77-84.

BRADFORD MM. 1976. A rapid and sensitive method for the quantization of microgram quantities of protein utilizing the principle of protein-dye binding. Analytical Biochemistry 72: 248-254.

CANO MP. 1997. Differences among Spanish and Latin-American banana cultivars: morphological, chemical and sensory characteristics. Food Chemistry 59: 411-19.

DEMIR Y; KOCAÇALISKAN I 2001. Effects of $\mathrm{NaCl}$ and proline on polyphenol oxidase activity in bean seedlings (Phaseolus vulgaris) grown by embryo culture. Biologia Plantarum 44: 607-609.

FAGERIA NK; SOARES FILHO WS; GHEYI HR. 2010. Melhoramento genético vegetal e seleção de cultivares tolerantes à salinidade. In: GHEYI HR; DIAS NS; LACERDA CF (eds). Manejo da salinidade na agricultura: Estudos Básicos e Aplicados. Fortaleza: INCT Sal. p. 206-217.

FLOWERS TJ. 2004. Improving crop salt tolerance. Journal of Experimental Botany 55: 307-319.

FOYER CH; NOCTOR G. 2009. Redox regulation in photosynthetic organisms: signaling, acclimation, and practical implications. Antioxidants \& Redox Signaling 11: 862-905.

FURLANI PR. 1998. Instruções para o cultivo de hortaliças de folhas pela técnica de hidroponia NFT. Campinas: IAC, 30 p. (IAC. Boletim Técnico, 168).

GOMES MRA; OLIVEIRA MGA; CARNEIRO GES; BARROS EG; MOREIRA MA. 2001. Propriedades físico-químicas de polifenoloxidase de feijão (Phaseolus vulgaris). Ciência \& Tecnologia de Alimentos 21: 69-72.

KAVI KISHOR PB; SANGAM S; AMRUTHA RN; LAXMIP SRI; NAIDU KR; RAO KRSS; RAO S; REDDY KJ; THERIAPPAN P; SREENIVASULU N. 2005. Regulation of proline biosynthesis, degradation, uptake and transport in higher plants: Its implications in plant growth and abiotic stress tolerance. Current Science 88: 424-438.

KOCA H; BOR M; OZDEMIR F; TÜRKAN I. 2007. The effect of salt stress on lipid peroxidation, antioxidative enzymes and proline content of sesame cultivars.
Environmental and Experimental Botany 60: 344-351.

MAIA JM; VOIGHT EL; MACEDO CCE; FREITAS JBS; SILVEIRA JAG. 2010. Antioxidative enzymatic protection in leaves of two contrasting cowpea cultivars under salinity. Biologia Plantarum 54: 59-163.

MADHANIAS; MADAN S; SAWHNEY V. 2006. Antioxidant defense mechanism under salt stress in wheat seedlings. Biologia Plantarum 50: $227-231$.

MELONI DA; OLIVA MA; MARTINEZ CA; CAMBRAIA J. 2003. Photosynthesis and activity of superoxide dismutase, peroxidase and glutathione reductase in cotton under salt stress. Environmental and Experimental Botany 49: 69-76.

MILLER G; SUZUKI N; CIFTCI-YILMAZ S; MITTLER R. 2010. Reactive oxygen species homeostasis and signaling during drought and salinity stresses. Plant, Cell and Environment 33: 453-467.

MITTLER R. 2002. Oxidative stress, antioxidants and stress tolerance. Trends Plant Science 7: 405-410.

MOLDES CA; MEDICI LO; ABRAHÃO OS; TSAI SM; AZEVEDO RA. 2008. Biochemical responses of glyphosate resistant and susceptible soybean plants exposed to glyphosate. Acta Physiologiae Plantarum 30: 469-479.

MUNNS R. 2002. Comparative physiology of salt and water stress. Plant, Cell and Environment 25: 239-250.

MUNNS R; TESTER M. 2008. Mechanisms of salinity tolerance. Annual Review Plant Biology 59: 651-681.

SAIRAN RK; RAO KV; SRIVASTAVA GC. 2002. Differential response of wheat genotypes to long-term salinity stress in relation to oxidative stress, antioxidant activity and osmolyte concentration. Plant Science 163: 1037-1046.

SILVAAO; SILVADJR; SOARES TM; SANTOS AN; ROLIM MM. 2011. Produção de rúcula em sistema hidropônico NFT utilizando água salina do Semiárido - PE e rejeito de dessalinizador. Revista Brasileira de Ciências Agrárias 6: 147-155.

SUDHAKAR C; LAKSHM I A ; GIRIDARAKUMAR S. 2001. Changes in the antioxidant enzyme efficacy in two high yielding genotypes of mulberry (Morus alba) under $\mathrm{NaCl}$ salinity. Plant Science 161: 613-619.

WILLADINO L.; GOMES EWF; SILVA EFF; MARTINS LSS; CAMARA TR. 2011. Efeito do estresse salino em genótipos tetraplóides de bananeira. Revista Brasileira de Engenharia Agrícola e Ambiental 15: 53-59. 